\title{
Internet Economy and Startup Business Development and Policy in Economic Law Perspectives
}

\author{
Edi Krisharyanto* and Ari Purwadi
}

Faculty of Law, Universitas Wijaya Kusuma Surabaya, Indonesia

\begin{abstract}
This study aims to analyze the development of startup business in Indonesia which is facing legal and regulatory barriers, namely legal issues, taxation, employment, intellectual property rights. By using a conceptual and empirical approach, the results showed that the fundamental legal problem faced by startup business in Indonesia is about the legality of establishing a startup business. Moreover, it relates to the legal standing of a business entity and its legal accountability. The theoretical implication of the findings underlines the startup business settings which are in need to be developed in the realm of economic law that leads to the regulation and legal thinking of ways to support the national economy. The practical implications suggest the development of startup business as a pioneering business entity in the field of commerce based on entrepreneurship and the internet economy.
\end{abstract}

Keywords: Startup business, economic law, internet.

\section{INTRODUCTION}

The development of economic globalization began with the birth of the Industrial Revolution 4.0. the latest technological developments are followed by business advancements. Such rapid progress has led to creative and innovative ideas based on technology. Current developments and technological advancements in the Industrial Revolution 4.0 era demanded that the Indonesian people follow these developments and progress.

Lately, the development of startup business in Indonesia has increased. Start-up businesses are driven by adequate information technology infrastructure capital, making it easy for the public to meet their daily needs. Expansion of transaction space for goods and services produced domestically and abroad produced offered thanks to advances in technology, telecommunications, and information. In 2020 the Government of Indonesia wants to position Indonesia as the largest Digital Economy Country in Southeast Asia. At this time, startup e-commerce businesses both online trading and digital startups with fresh and innovative ideas need to be encouraged to grow into new technopreneurs, either by cooperating with leading technopreneurs mentors, data centers, technoparks, and providing funding (Lukito, 2017).

The United States-ASEAN Business Council states that startups in Indonesia have enormous potential, so the government is expected to implement appropriate policies to support these companies. Furthermore Marc

*Address correspondence to this author at the Faculty of Law, Universitas Wijaya Kusuma Surabaya, JI. Dukuh Kupang XXV - 54 Surabaya, East Java 60225, Indonesia; E-mail: edykhy.uwks@yahoo.com
Mealy stated, the whole world recognized the real growth potential offered by startups in the Southeast Asian region, but without the support of proper regulations and regulations, startups would be difficult to develop (Maulana, 2019). On the world side, tertiary institutions have been initiated to develop technologybased startup companies in the face of the industrial revolution 4.0 era through the concept of optimizing the Technology-Based Starter Company (PPBT) policy instrument, for startups/technology startups through the incubation process by the Business Incubator Institute. The program implemented at the end of 2019 is expected to grow 1,000 (one thousand) technology startups. The program equips startup founders with business funding, skills, and knowledge needed to minimize failure and become a quality startup (https://www.ristekbrin.go.id, 2018). The effort to print the birth of 1000 Digital Startups will continue in 2019, to build a national digital economic ecosystem. PPBT by relying on technology was also able to print new jobs and indirectly also improve community welfare. The PPBT program aims to enable young Indonesians to be creative and continue to innovate in the face of the development of digital technology (http://itechmagz.id/, 2018).

The rapid development of technology and information through the internet opens opportunities for new business activities. One new form of business is done through e-commerce. At present, it is easier to get access both through quota purchases and through hotspot media that are scattered in various places to facilitate access to the internet. With the development of technology and information via the internet, a startup business has emerged. A startup business is a trading business activity that starts its business activities by 
offering goods and services. A startup business is a business that has a business process that is very closely related to the internet. Therefore, it can be said, that startup business activities will not run without the internet. Indonesia's startup business is highly dominated by e-commerce because it cannot be separated from the development of buying and selling that is carried out on-line in Indonesia. With ecommerce, it can be said of the use of simple technology, where a person can offer goods and or services on a website, which is expected to bring together business people with consumers, and make it easy for people to get their needs without going anywhere.

A startup business is a business or activity in the field of trade. Theoretically, trading activities are regulated through the field of law called economic law. Smitthoff (1977) said that economic law is a legal arrangement with government interference in trade, industry, and financing. To put economic law as an instrument to support trading activities through startup business development policies, it seems necessary to know what role the economic law wants from the existence of startups in the community.

The purpose of this paper is to determine the legal problems that occur in startup business development policies and to analyze the role of economic law in startup business development policies in Indonesia. Thus the discussion in this paper revolves around whether the legal problems faced in startup business development policies and how the role of economic law in startup business development policies in Indonesia.

\section{METHOD}

This research uses the normative legal research method. The normative legal research method is research that conducts a literature review through document studies, namely by using secondary sources such as legislation, court rulings, legal theories, and opinions of legal experts relating to startup development policies in Indonesia. Judging from the problem approach used, this study uses a statutory approach.

\section{Legal Problems Faced in Startup Business Development Policies}

The internet is inevitably the lungs of startup business activities. Therefore, the rapid development of internet usage in Indonesia is the basic capital for the development of startups in Indonesia. The profile of
Internet users in 2012 reached around 55 million Indonesians who have been accessed by information and communication technology-based media. Whereas the data in June 2019 grew, namely internet users in Indonesia had reached $171,260,000$ based on data from Internet World Stats, 2019. Thus, there was a rapid increase in internet users in Indonesia during the 2012 to 2019 range of $311 \%$.

Based on the survey report of the Indonesian Internet Service Providers Association (APJII) 2018, the number of internet users in the country reached 171.17 million people, or $64.8 \%$ of the total population of 264.16 million people. By region, Java is still the biggest internet user, reaching $55 \%$. Bali and Nusa Tenggara have the smallest internet users, only $5 \%$. The contribution of internet users in Sumatra by $21 \%$, Sulawesi-Maluku-Papua by $10 \%$, and Kalimantan by 9\%. The APJII Survey was conducted on March 9-April 14, 2019 in collaboration with the Indonesian Poll. Respondents numbered 5,900 throughout Indonesia with a margin of error of $1.28 \%$. Data collection techniques with interviews and questionnaires, as well as research methods with probability sampling and multistage random sampling (https://databoks.katadata.co.id, 2019).

The mapping of startup database in Indonesia in 2018 presented by the Indonesia Digital Creative Industry Community and the Indonesian Creative Economy Agency showed there are 992 Indonesian startups.

According to Bednár and Tarišková (2017), there are 5 of the most serious startup problems including lack of money for further development; products/services that are not needed on the market; no investors; cost issues; and incorrect team.

Furthermore, it was said, that the main purpose of establishing a startup was to find new markets and create high value-added products. In the beginning, startups were low-cost projects that were mostly made by programmers and designers who wanted to make something unique and produce a lot. However, in more than $90 \%$ of cases, they fail. Three of the five main problems related to finance - either wrong pricing of products, bad cost estimates, or lack of capital for further development. The second major problem is the lack of market needs - inadequate product testing results in the real market. The fifth biggest problem is the poor team who cannot solve the problem and cannot develop their Minimum Viable Product business 
Table 1: Indonesian Startups Mapping

\begin{tabular}{|c|c|c|c|c|}
\hline Classification & Freq. & $\%$ & Classification & $\%$ \\
\hline \multicolumn{3}{|l|}{ Location: } & \multicolumn{2}{|l|}{ Business Scale: } \\
\hline Greater Jakarta & 522 & 52.62 & Big & 3.12 \\
\hline Java Provinces & 241 & 24.29 & Medium & 11.90 \\
\hline Lesser Sunda Islands & 32 & 3.23 & Micro & 52.97 \\
\hline Kalimantan & 24 & 2.42 & Small & 32.01 \\
\hline Sulawesi & 34 & 3.43 & \multicolumn{2}{|l|}{ Main Problem: } \\
\hline Sumatra & 115 & 11.53 & Capital & 38.82 \\
\hline Unknown & 24 & 2.42 & $\mathrm{HR}$ & 29.41 \\
\hline \multicolumn{3}{|l|}{ Legal entity: } & Amenities & 15.00 \\
\hline Limited partnership (CV) & 522 & 6.96 & Market & 7.94 \\
\hline LLC & 540 & 54.44 & Regulations and Laws & 8.82 \\
\hline Non-legal entity & 113 & 11.39 & \multicolumn{2}{|l|}{ Scale \&Regulatory issues: } \\
\hline Unknown & 270 & 27.22 & Big & 29.41 \\
\hline \multicolumn{3}{|l|}{ Business sector: } & Medium & 12.50 \\
\hline E-Commerce & 352 & 35.48 & Micro & 5.20 \\
\hline Financial technology & 53 & 5.34 & Small & 7.96 \\
\hline Games and entertainment & 55 & 5.54 & & \\
\hline Others & 532 & 53.63 & & \\
\hline
\end{tabular}

model. Natasha Evers (2003) it was said that a further inhibiting factor for the process of starting was obtaining legal recognition of a business. Government regulations can be very strict in developing countries where registering new companies is a time-consuming and expensive process.

Legal problems at startup as stated by Kameliya Nikolaeva Marinova (2018) in Bulgaria are related to some issues. First, tax issues must be considered carefully concerning reducing the risk of possible violations that can lead to large fines, lawsuits, or in the worst case of imprisonment. Second, problems with permits and licenses. Equally important for startup companies remains the problem with permits and licenses needed for their business. Failure to follow permits and licensing regulations can result in fines, lengthy and expensive lawsuits, and in some cases more seriously stop business activities or close down the company. Therefore, novice companies should consider the above mentioned to avoid possible violations that can adversely affect their business. Third, protection of intellectual property. Intellectual property includes copyrights and related rights and industrial property such as patents, brands, designs. Fourth, unfair competition. In general, the main purpose of competition law is to control the competitive environment and protect consumers. a big problem for any startup company that has an unfair competition problem because it might not be well protected. Fifth, labor-related issues. what must be taken into account in the making and implementation of employment contracts, documenting workers, avoiding discrimination recruitment, working conditions. Sixth, inadequate legislation. Problems can occur not only because there are no specific regulations for the startup business, but also the existing regulations cannot protect the rights of startup companies or hold them back from taking certain actions.

In Indonesia, 5 legal issues are often faced by startup businesses. Problems of the legality of business entities: not having business licenses and choosing legal forms of business entities. The choice of legal form for the business entity is very important to determine the licensing process and legal responsibility of the founder of the business entity. In terms of taxation issues, there is a need to have a Taxpayer Identification Number for requirements for filing legality of business entities, such as Company Business Licenses and Company Registration Certificates and ignoring obligations as taxpayers, business entities will be faced with obstacles or problems if they want to take care of other things, such as for file as a Taxable 
Entrepreneur. Moreover, regarding Intellectual property rights issues, startups that sell software should not ignore the need to protect intellectual property rights, because after all the software has economic value for the company and is useful for controlling the use of the software. In terms of employment issues, there is clear information to employees such as salary, income tax, health insurance, employment insurance, bonuses, and clear company regulations and employment contracts are needed. Lastly, issue of the shareholder agreement, a legal engagement cannot be based on trust, so a contract is needed so that the authority of each shareholder is known and the terms of the sale of shares.

\section{The Role of Economic Law in Startup Development Policies in Indonesia}

Economic law focused on the development and social-economic law. Economic law had 2 aspects of regulating economic development efforts to improve people's economic lives, and of regulatory aspects efforts to share the results of economic development to all people equally. Indonesia's economic law is divided into economic law of development, namely the regulation and legal thinking on ways to increase and develop the national economy, and social-economic law, namely the regulation and legal thinking about ways of sharing the results of national economic development fairly and evenly (Sumantoro, 1987). Classification of economic laws for new fields of law that have not been included in economic law includes, among others: intellectual property rights law, business competition law, consumer protection law, capital market law, investment law, electronic commerce law, entrepreneurship law, computer law, and sports law.

According to Rowley (1988), that legal economic analysis, or law and economics, can be defined as the application of economic theory and econometric methods to test the formation, structure, process, and impact of law and legal institutions. This approach is recommended not only for legal rules with clear links to economic realities such as competition, economic organization, prices and profits, and income distribution, which translates into competition law, industrial regulation, labor law, and tax law. Law and economics have the ambition of applying an economic approach not only to fields of economic regulation that are easily related to economics but to all fields of law. In economic regulation, legal economic analysis will provide an understanding of the forces that control redistribution that demonstrate legal restrictions on the behavior of market participants, elaborated by legislators, courts, or administrative institutions (Mackaay, 2000).

Law and economics, also known as legal economic analysis, differs from other forms of legal analysis in two characteristics: First, the theoretical analysis focuses on efficiency, and Second, the emphasis is on incentives and people's responses to these incentives (Rubin, 2008). Economic efficiency refers to the most valuable use in the allocation and distribution of all factors of production in an economy. This also includes minimizing production costs and maximizing output (Heyne, 2008). According to Petrou (2014),

"Economic efficiency is a broad term typically used in microeconomics to denote the state of best possible operation of a product or service market. Economic efficiency assumes the minimum cost for the production of a good or service, maximum output, and maximum surplus from the operation of the market."

From a social perspective, Jovanovic (2001) socially depicted that:

"Economic efficiency dictates that people who start as equals should sometimes end up different."

While in a more technical term, Whittaker (2014) assumed that the model of input-output in economic efficiency is more properly called allocative efficiency.

"[It] concerns producing the maximum output subject to inputs, i.e., it is not possible to increase output simply by reallocating resources, and it is achieved by equalizing the marginal capacity to benefit from additional funds across all inputs."

From a social perspective, Russell Hardin (1992) examines morality in law and economics stating that normative and economic law presents us with the most developed and coherent theory of moral law that we have not yet seen. One might object to its moral principles, but one cannot do so by referring to an explanation of comparable normative law. The microeconomic theory itself grows out of normative concern, especially with welfare. The most prominent feature of law and economics, however, is that its moral principles are extraordinary. The initial concern 
with efficiency is to avoid claims of aggregate welfare. Vilfredo Pareto seeks a minimum moral principle that everyone can agree on: A change is good if it helps some people and does not hurt anyone.

Startups can be divided into two types, namely ecommerce startup and FinTech startup. An ecommerce startup is a form of business entity that provides an online trading transaction platform. While the FinTech startup is a form of business entity that develops innovations that give birth to services in the field of financial services through the adoption of technological sophistication(Fitriana, 2018). Initially, the startup business refers to start-up companies or those that have not been in operation for a long time, because most of them are newly established and are in a position of being in the development and research phase to find the right market. In the end, these startups have developed very quickly by relying on the use of digital technology that facilitates interaction between business entities with millions of potential customers (Sub Directorate of Welfare and Entrepreneurship of the Director-General of Learning and Student Affairs of the Ministry of Research, Technology and Higher Education, 2019). Currently, the startup business is associated with various information technology-based startups through the use of the internet. Information and communication technology that is developing at this time, in essence, can be used to improve the welfare of the community in building a nation or world civilization. Information and communication technology has shown an important change in the development of civilization, especially the world economy (Kristiyono, 2015). According to Salamzadeh and Kawamorita (2015), the theory of entrepreneurship is the most dominant theory in entrepreneurial business. First, entrepreneurship is related to ideas, creativity, innovation, development of new products or services, opportunities, and the like. As such, the entrepreneurial theory is more likely to be considered at the initial stage of any business or organization. Secondly, going beyond entrepreneurial theory, organizational and management theory will emerge, which is related to managing people and organizations. Third, the startup is about turning ideas into business which is a critical point in entrepreneurial studies such as new business creation, value creation, and recognition of opportunities, evaluation, and exploitation. Thus, the startup business is part of the field of study of Economic Law.

Regulations related to startup business in Indonesia which are part of the field of Economic Law include:
Law Number 20 of 2008 concerning Micro, Small and Medium Enterprises; Law Number 33 of 2009 concerning Film to motivate the development of the film industry; Law Number 3 of 2014 concerning Industry to motivate the development of national creative industries; Law Number 28 of 2014 concerning Copyright, namely to provide intellectual property protection for creative works; Law Number 13 of 2003 concerning Manpower to protect workers; Law Number 5 of 1999 concerning Prohibition of Monopolistic Practices and Unfair Business Competition to protect business actors from unfair competition; Law Number 7 of 2014 concerning Trade, which is to motivate trade in products based on creative economy; and Law Number The regulations relating to startup business in the form of e-commerce include: Law Number 11 of 2008 concerning Information and Electronic Transactions; Government Regulation Number 82 Year 2012 concerning Operation of Electronic Systems and Transactions as amended by Act Number 19 of 2016; Regulation of the Minister of Communication and Information Technology Number 20 Year 2016 concerning Protection of Personal Data in Electronic Systems; Regulation of the Minister of Communication and Information Technology Number 36 Year 2014 concerning Procedures for Registration of Electronic System Organizers. In connection with the establishment of a startup business based on the form of a business entity regulated in the Commercial Law Code for regulating the establishment of a Vennootschap Commanditaire, Law Number 40 of 2007 concerning Limited Liability Companies.

The internet economy is broadly defined as economic activity either supporting the Internet or fundamentally dependent on the existence of the Internet. Consolidation in the internet economy can influence the evolution of the Internet organized around three separate but closely related economic domains, namely Internet Applications (how to communicate, share and be innovative; Terms of Access (how tobe connected); and infrastructure services (how to build the sustainability of the internet), (Internet Society Global Internet Report, 2019).

Applications and services shape the experience of internet users and allow them to communicate, share and innovate. The internet is the interconnection of computers throughout the world in tens of thousands of networks run by various organizations. Access to the internet allows users to connect to information and communication technology (ICT) throughout the world. Physical access is measured using metrics such as 
availability, quality, and price of connectivity and service. Internet access and adoption are both influenced by factors that are not easily measured and are often deeply rooted in society, including education levels (which tend to have an impact on digital literacy skills), income levels (which have an impact on the cost and affordability of broadband and devices), infrastructure development (especially in rural areas), the availability of relevant content (which influences whether people want to get access), and various cultural and structural factors that can influence adoption. The open and decentralized nature of the Internet means that, in principle, anyone can manage network services, which include networks and devices within the home and company, as well as Internet network service providers that connect these homes and companies to the global Internet.

\section{Internet Economy and Future Projection of Startup Business}

There is a crucial factor in the growth of startup businesses in the form of the work experience of entrepreneurs (Perdani et al., 2018). However, at least the potential for Indonesian internet users which is increasing from year to year is certainly land to establish a startup business. In terms of policy regulations and incentives to increase the capacity and protection of startup business businesses by making efforts so that startups can obtain intellectual property rights (IPR) and micro-small business permits. The data available in 2018 were $52.97 \%$ of microbusinesses and $32.01 \%$ of small-scale businesses that had to be sought to obtain a business license and assistance for the acquisition of intellectual property rights.

Based on data in 2018 as many as $11.39 \%$ have not been incorporated and $27.22 \%$ of legal entities are unknown. The fundamental legal problem is the legality of a startup business entity because, with the receipt of a business entity establishment license, it will have legal standing, so that inherent legal responsibilities are attached to a startup business entity. The legality of this startup business entity is needed for registration as an electronic system provider so that there is protection for consumers.

This startup business is budding, so you need to think about your capital and which parties will join as shareholders. Determination of the scale of the amount of paid-up capital is very dependent on the agreement of the shareholders and related parties. The scale in determining the amount of paid-in capital also depends on the agreement of the shareholders and related parties, all of which must be framed in a shareholder agreement. Regarding taxation, employment, and intellectual property issues, there are provisions governing these matters, which also apply to businesses in startup businesses.

This startup business is a pioneering business in the field of the trade so that it is very feasible to enter into the realm of Economic Law so that regulation and legal thinking focus on ways to improve and develop the national economy. From the perspective of economic law analysis, the startup business development policy must lead to efficiency. The startup business development policy aims to make it easy for the community to meet their daily needs on the one hand and the one that leads to people's welfare because it absorbs new jobs and fosters an entrepreneurial spirit. Such an objective must of course be followed by the development of facilities so that efficiency occurs. The development of the required facilities is in the form of proper regulations and regulations. Startup business is related to ideas, creativity, innovation, development of new products or services, opportunities, and the like, so it's not wrong to say that business is based on entrepreneurship. The startup business is fundamentally business dependent on the existence of the Internet, so it attaches to the characteristics of the internet economy that is organized through the economic domain, namely internet applications, access provisions, and infrastructure services.

\section{CONCLUSION}

Legal issues that arise in the startup business revolve around issues of legality, taxation, employment, intellectual property rights, and shareholder agreements. The legality issue of a startup business entity is a baseline problem because it relates to the legal standing and accountability of the business entity, while for other legal issues it would have been regulated by applicable regulations. However, specifically regarding the issue of the shareholder agreement, because it is included in the civil realm, it depends on the agreement of the parties, namely the founder of startups and shareholders.

In connection with Economic Law, a startup business is a starter business based on entrepreneurship, so a startup business development policy is needed by establishing an entrepreneurial law. 


\section{REFERENCES}

Bednár, R., \& Tarišková, N. (2017). Indicators of startup failure. Industry 4.0, 2(5), 238-240.

Databoks.katadata. (2019). Survei APJII: Pengguna Internet Masih Terkonsentrasi di Jawa. Retrieved February 8, 2020 from https://databoks.katadata.co.id/datapublish/2019/05/16/surve i-apjii-pengguna-internet-masih-terkonsentrasi-di-jawa.

Evers, N. (2003). The process and problems of business startups. The ITB Journal, 4(1), 3

Fitriana R. (2018). The Effect of Financial Technology on the Encouragement of Startup Formation in Indonesia. Paper presented at the Transformative Power of Fintech: Call for the Essay and Strategic Seminar 2018. Maksi FEB UGM.

Hardin, R. (1992). The morality of law and economics. Law and Philosophy, 11(4), 331-384. https://doi.org/10.1007/BF01003982

Heyne, P. (2008). Efficiency. The Concise Encyclopedia of Economics.

Internet Society Global Internet Report. (2019). Consolidation in the Internet Economy. Internet Society Global Internet Report, pp. 18-27.

Itech. (2018). Ini Perkembangan 1000 Startup Dukung Ekosistem Ekonomi Digital.Retrieved February 6, 2020 from http://itechmagz.id/corporate-updates/ini-perkembangan1000-startup-dukung-ekosistem-ekonomi-digital/.

Jovanovic, B. (2001). Economic Growth: Theory, in Smelser, N. J., \& Baltes, P. B. (Eds.), International encyclopedia of the social \& behavioral sciences (Vol. 11). Amsterdam: Elsevier. https://doi.org/10.1016/B0-08-043076-7/02309-3

Kemenristekdikti Press Release. (2018). Kemenristekdikti Provides Activists with Startup Knowledge and Skills for Developing Companies Through PPBT Business Camp Training. Retrieved February $6, \quad 2020$ from https://www.ristekbrin.go.id/siaran-pers/kemenristekdiktibekali-pegiat-startup-pengetahuan-dan-keterampilanmengembangkan-perusahaan-melalui-pelatihan-ppbtbussiness-camp-2/.

Kristiyono, J. (2015). Internet Culture: The Development of Information and Communication Technology in Supporting the Use of Media in Society. Scriptura, 5(1), 23-30. https://doi.org/10.9744/scriptura.5.1.23-30

Lukito, I. (2017). Legal Challenges and the Role of Government in eCommerce Development. Scientific Journal of Legal Policy, 11(3), 349-367.

Mackaay, E. (2000). History of Law \& Economics (0200).
Marinova K N. (2018). Business and Legal Problems of Startup Companies in Bulgaria. (Master Thesis Tilburg Law School).

Maulana V. (2019). US-ASEAN Business Council: Indonesia's Startup Potential is Extraordinary. Retrieved February 6, 2020 from https://ekbis.sindonews.com/read/1428056/34/dewan-bisnisas-asean-potensi-startup-indonesia-luar-biasa-1565264364.

Perdani, M.D.K., Widyawan, \& Santoso, P.I. (2018). Factors That Influence Startup Growth in Yogyakarta. Paper presented at the 2018 National Information and Communication Technology Seminar (SENTIKA 2018) Yogyakarta, 23-24 March 2018, $p$ 337-349.

Petrou A. (2014) Economic Efficiency. In: Michalos A.C. (eds) Encyclopedia of Quality of Life and Well-Being Research. Springer, Dordrecht. https://doi.org/10.1007/978-94-007-0753-5 818

Rowley, C. K. (1988). Rent-seeking versus directly unproductive profit-seeking activities. In The Political Economy of RentSeeking (pp. 15-25). Springer, Boston, MA. https://doi.org/10.1007/978-1-4757-1963-5 2

Rubin, P. H. (2008). Law and economics. In the concise encyclopedia of economics. Liberty Fund. Available at www. econlib. org/library/Enc/LawandEconomics. html.

Salamzadeh, A., \& Kawamorita Kesim, H. (2015). Startup companies: Life cycle and challenges. In 4th International conference on employment, education and entrepreneurship (EEE), Belgrade, Serbia. https://doi.org/10.2139/ssrn.2628861

Schmitthoff, C. M. (1977). Group Liability of Multinationals. Legal Problems of Multinational Corporations, 82.

Smitthoff C. (1977). The Concept Law of Economic in England. London: Stevens \& Sons, p 39.

Sub Directorate of Welfare and Entrepreneurship of the Director General of Learning and Student Affairs of the Ministry of Research, Technology and Higher Education. (2019). Indonesian Student Startup Acceleration. Jakarta: Sub Directorate of Welfare and Entrepreneurship of the Director General of Learning and Student Affairs of the Ministry of Research, Technology and Higher Education.

Sumantoro (1987). Multinational Corporate Activities, Political and Economic Problems in National Development. Jakarta: Gramedia.

Whittaker, W. (2014). Resource Allocation Funding Formulae, in Encyclopedia of Health Economics. Amsterdam: Elsevier. https://doi.org/10.1016/B978-0-12-375678-7.00211-X

https://doi.org/10.6000/1929-4409.2021.10.80

(c) 2021 Krisharyanto and Purwadi; Licensee Lifescience Global.

This is an open access article licensed under the terms of the Creative Commons Attribution Non-Commercial License (http://creativecommons.org/licenses/by-nc/3.0/) which permits unrestricted, non-commercial use, distribution and reproduction in any medium, provided the work is properly cited. 